\title{
Sangværket som udviklingsroman \\ Om Randi Habersaat Rodes bog \\ Barneglad og engleklog (1996)
}

\section{Af Sune Auken}

Grundet et antal uheldige omstændigheder har Randi Habersaat Rodes bog Barneglad og engleklog, skønt den blev udgivet i 1996, først nu kunnet omtales i Grundtvig-Studier. Det er en skam, for der er flere gode grunde til, at Grundtvigforskningen bør tage Randi Rodes bog alvorligt. For Barneglad og engleklog er den første egentlige monografi om Grundtvigs salmedigtning i den nyere Grundtvigforskning, og mere end det: bogen gennemarbejder et tekstkorpus, som ikke tidligere har været behandlet som sådant $\mathrm{i}$ forskningen, og fremsætter en interessant tese om dette centrale korpus i Grundtvigs forfatterskab, en tese, som må tages alvorligt. Af videre vigtighed er dette arbejde, fordi der trods adskillige forskeres udmærkede indsats ofte går mange år imellem de større egentlige litteraturvidenskabelige afhandlinger. Ser vi bort fra Poul Borums Digteren Grundtvig, der mere er journalistisk end videnskabelig i sit anlæg, skal vi sådan set helt tilbage til Flemming Lundgreen-Nielsens disputats i 1980 for at finde et større samlet litteraturvidenskabeligt arbejde om Grundtvig.

Det tekstkorpus, Randi Rode behandler i sin bog, er Grundtvigs Sang-Vark til den danske Kirke (1836-37), eller rettere de første 146 salmer af dette værk. Barneglad og engleklog gennemgår salmerne en ad gangen i et fors $\varnothing \mathrm{g}$ på at vise en indre sammenhæng imellem dem. Når det kun er denne første del, Rode behandler, er det, fordi den anden del af sangværket har sin egen og mere velkendte komposition, hvor de kirkelige højtider behandles en for en med salmer hentet fra de seks første af de syv såkaldte hovedmenigheder, Grundtvig ser i kirkehistorien. Rodes tanke er, som hun udtrykker det i sin konklusion, »det gennemkomponerede værk«,

$<\ldots>$ at salmerne i denne første del kan læses som en beretning om digterens egen udviklingshistorie, hans kamp for at finde sin identitet som digter, mand og reformator. <...> Man kan muligvis endog - hvad For-Spil peger på - betragte denne del som en fortsættelse af »Nyaars-Morgen«. (173) 
Hvis denne tese er rigtig, har Rode begået noget af et kup, nemlig at identificere endnu et betydeligt lyrisk-episk værk i Grundtvigs forfatterskab ved siden af de andre stordigte i forfatterskabet, RoskildeRiim, Et Blad af Jyllands Rimkrønike, Nyaars-Morgen, Christenhedens Syvstjerne osv., og hun har samtidig bidraget væsentligt til forståelsen af et af Grundtvigs og dansk litteratur- og kirkehistories vigtigste værker.

Dette sidste kan ingen under nogen omstændigheder tage fra hende. I bestræbelsen på at dokumentere sin tese og drage konsekvenserne af den, gennemgår Randi Rode sangværkets forspil såvel som samtlige salmer i første del, og det er i sig selv en præstation. At forholdet imellem det høje antal analyser og det lave antal sider i bogen så forhindrer Rode i at komme i dybden med den enkelte tekst, er beklageligt, hvis det er enkeltsalmerne man interesserer sig for, men det, at der nu overhovedet er lavet et udspil på hver enkelt af disse salmer, er der i sig selv grund til at glæde sig over.

Den udviklingshistorie, Rode beskriver, lægger sig for hende $\mathrm{i}$ forlængelse af Nyaars-Morgen (1824) og optræder som en fornyet løsning i forhold til dette værks for tidlige proklamation af en triumf. Det ser Rode bekræftet i det udvalg af strofer fra Nyaars-Morgen, Grundtvig har sat sammen til sangværkets For-Spil. I stedet for at slutte med den sejrsstemning, som dominerer slutpunktet i det oprindelige digt, slutter teksten her midt i natten og midt i vinteren, endda Fimbulvinteren, på det punkt, hvor Nyaars-Morgens oprindelige 4. sang sluttede. Fra dette punkt søger Barneglad og engleklog nu at påvise, hvordan sangværkets første 146 salmer udgør en kæde af salmer, der beskriver Grundtvigs udvikling frem imod alderdom og modenhed. Det er Randi Rodes udlægning, at de to først udkomne hefter af sangværket beskriver Grundtvigs personlige udvikling, som menneske, som digter, som troende og som kønsvæsen og bl.a. indbefatter en forståelse af forholdet imellem det mandlige og det kvindelige, som nedbryder misvisningerne $\mathrm{i}$ den mandlig bevidsthed for at nå frem til kvindernes sandere opfattelse af menneskelivet og af kristendommen. De næste hefter beskriver så (frem til midt i 4. hefte), hvordan der med udgangspunkt i den foregående udvikling kan danne sig en grundtvigsk menighed, altså en bevægelse fra det subjektive ind i det objektive. Barneglad og engleklogs egentlige interesse samler sig om de første to hefter og dermed om at beskrive den personlige udvikling, Grundtvig her ifølge Randi Rode skildrer. 
To spørgsmål trænger sig på for mig i forbindelse med Barneglad og engleklog. Det drejer sig dels om det grundlæggende teoretiske greb i bogen, og dels om bogens analytiske hovedtese. På begge punkter er jeg meget $i$ tvivl om, hvor vidt jeg kan tilslutte mig bogens antagelser og synspunkter.

Randi Rode betegner sit teoretiske grundlag som »Den intertekstuelle metode«. Hendes beskrivelse af denne metode er imidlertid påfaldende kort. Afsnittet om metoden strækker sig kun over lige knap to sider, og hvad hun her faktisk siger om begrebet »intertekstualitet «, er så kortfattet, at det lader sig citere i sin helhed under udeladelse af en enkelt fodnote:

Begrebet intertekstualitet bruges især om implicitte og eksplicitte relationer mellem en forfatter og hans litterære forgængere, en eller flere såkaldte intertekster (engelsk: intertexts), som han i det aktuelle værk forholder sig mere eller mindre bevidst til (»Intertextuality«, s. 22). Eftersom metoden kan bruges på »(..) everything, be it explicit or latent, that links one text to another (..) «(s. 22), kan den også bruges til at beskrive forholdet mellem en forfatters enkelte værker. Væsentligt for den intertekstuelle tekstlæsning er, at læseren antager, at der eksisterer sådanne relationer mellem teksterne, således at en mere eller mindre bevidst søgning sættes i gang under det analytiske arbejde (s. 26), dvs. at læserens intertekstuelle »drive « (s. 77) kan udfolde sig. Metoden forudsætter en gentagen læsning af den enkelte tekst, og interteksten vil ofte fremstå som noget, der fornemmes som en mangel for at forstå teksten fuldt ud, »(..) (the readers) perceive that something is missing from the text: gaps that need to be filled, references to an as yet unknown referent (..)«(s. 56-57). (15) ${ }^{1}$

Der er ikke på den måde noget i vejen med en passage som denne, og der står ikke noget i den, jeg er uenig med. Problemet er imidlertid, at det som teoretisk grundlag betragtet er uhyre spinkelt, og at hele bogens tesedannelse er båret af dette begreb. Barneglad og engleklog henviser uophørligt til dette intertekstualitetsbegreb, også på steder hvor man som læser sådan set ikke behøver oplysningen, hvad der godt kan virke lidt demonstrativt, ja, Randi Rode går så langt, at hun ligefrem kan henvise til, hvad en bestemt glose udløser hos »den intertekstuelle læser« (65). 
Denne manglende teoretiske refleksion er af betydning i forbindelse med Barneglad og engleklog, fordi Randi Rode med begrebet intertekstualitet både slører sit eget grundlæggende greb mere end helt godt er $o g$ forvolder en terminologisk usikkerhed i sin afhandling netop omkring dette begreb.

Randi Rode slorer sin metode, fordi netop den helhedslæsning af sangværket, Barneglad og engleklog udfolder, forudsætter, at forbindelsen imellem salmerne på værkets kompositoriske plan er at forstå tekstuelt og netop ikke udelukkende intertekstuelt. Sangværkets nr. 1 - 146 bør set fra Rodes synsvinkel i meget vid udstrækning opfattes som én tekst, og sådan aflæser hun det da også, fx når hun bruger et under omstændighederne meget langt afsnit (p. 69-73) på at behandle emnet »Afsnit 2 og 4 læst som slægtsdrama«.

Samtidig skaber Barneglad og engleklog uklarhed i sin terminologi, fordi værket ikke forholder sig til forskellen på et antal forskellige former for tekstuelle referencer, men blot taler om »intertekstualitet «. Man må som et absolut minimum skelne imellem fem typer tekstuelle referencer, bogen burde have forholdt sig til i forbindelse med sangværket:

I. Den rent tekstinterne (intratekstuelle) henvisning, altså det fænomen, at et stykke eller en formulering $i$ en tekst henviser til et andet i den samme tekst. Dette ligger rigtignok ikke inden for begrebet intertekstualitet, men netop når Rodes teknik får sangværkets første del til at fremstå som ét værk, skylder hun en redegørelse for, hvordan forholdet er imellem denne type tekstuel reference og så de talrige referencer rundt imellem forskellige salmer i det større værk, der i hendes optik udgøres af sangværkets første 146 salmer.

II. Den intertekstuelle reference imellem tekster internt i sangværkets nr. 1-146. Det er den type intertekstuel reference, Rode baserer hele sin læsning på, og som fortolker de 146 salmer til ét stort værk. Spørgsmålet her er bl.a., hvordan referencer imellem tekster på den måde kan gøre dem til et værk, der lader sig opfatte som sådan.

III. Den intertekstuelle reference til de tekster, Grundtvig har optaget og bearbejdet i sangværket, sine egne såvel som andres. Det er også et hyppigt behandlet fænomen i Rodes bog og er en helt anden form for intertekstualitet, end den, man finder i type II.

IV. Referencer til andre af Grundtvigs egne værker. Det er i tilfældet Barneglad og engleklog et helt særligt problem, fordi Randi Rode 
kun i meget sparsom form behandler denne type referencer, skønt de, så vidt jeg kan se, udgør en meget afgørende udfordring til hendes helhedslæsning. Det vender jeg tilbage til om et $\emptyset$ jeblik.

V. Referencer til andre værker end Grundtvigs egne, Bibelen, tidligere salmer, forskellige kirke-ånds- og litteraturhistoriske tekster. Skønt Barneglad og engleklog konstaterer en del af denne type intertekstualitetsforhold, afgiver bogen aldrig svar på, hvad der karakteriserer disse i sammenligning med de andre typer.

Her er type II og III speciel for sangværket, mens de øvrige er mere almindelige muligheder².

Uklarhederne omkring intertekstualitetsforholdene er så problematiske i forbindelse med Barneglad og engleklog, fordi det netop er dem, der er Rodes primære begrundelse for bogens bærende tese. Netop intertekstualiteten er nemlig et af de mest omfattende kritiske problemer i Grundtvigs forfatterskab, hvor alle de fem former for intertekstualitet er meget tydeligt repræsenterede. Den, som tydeligst har gennemarbejdet dette, er Helge Toldberg i Grundtvigs symbolverden (1950). Han påviser så mange gennemgående strukturer og billeder i Grundtvigs forfatterskab, at han på sin vis kommer til at arbejde ud fra en endnu mere radikal tese end Randi Rode, nemlig den, at forfatterskabet i sin helhed lader sig læse som ét værk. Og læser man i særdeleshed Grundtvigs poesi, kan man ikke lade være med at blive slået af, at Toldbergs tese er om ikke fuldstændig rigtig, så i hvert fald indlysende. Imidlertid har Randi Rode slet ikke reflekteret på denne del af Toldbergs arbejde, de seks henvisninger, Barneglad og engleklog rummer til Grundtvigs symbolverden, omhandler alle konkrete detailspørgsmål, og det er et stort problem, fordi det ikke kan afgøres på forhånd, om et genkommende element er en intertekstuel reference eller bare er et genkommende element. Et ekstremt eksempel kunne være, at Grundtvig både i Et Blad af Jyllands Rimkrønike fra 1815 og i Christenhedens Syvstjerne fra midt i halvtredserne såvel som en række andre steder henviser til fortællingen om, hvordan Freja græder guldtårer af længsel efter sin forsvundne ægtemand Odd. At det er en intertekstuel reference af type fem er indlysende nok, men er det også en intertekstuel reference af type fire? Viser Grundtvig i Christenhedens Syvstjerne tilbage til Et Blad af Jyllands Rimkrønike eller er det bare et genkommende element, hvis genkomst man rigtignok kan gøre til genstand for analyse, men som ikke betyder, at der eksisterer en i forfatterskabssammenhæng særlig tæt 
forbindelse imellem de to nævnte tekster. Det er et stort problem for en læsning som den, Randi Rode foretager, fordi det ikke er til at sige, om der er tale om referencer eller »bare « om paralleller, og dermed om sangværket udviser en speciel intern sammenhæng, som karakteriserer det i forhold til forfatterskabets andre tekster, eller om det bare er indlejret i Grundtvigs symbolverden som alle hans andre digte. Lad mig give et langt og et kort eksempel.

I forbindelse med sin gennemgang af sangværkets nr. 25, Er det muligt, er det sandt, bemærker Randi Rode følgende:

Salmen slutter med en årstidsmetafor, der sammen med bække-metaforen $(7,4)$ leder tanken hen på dagvisen $(\mathrm{nr} .14)^{3}$. Bækkene kan i nr. 14 opfattes som billeder på det kvindelige element, ligesom dette metaforisk fremstilles som fuglen, der let svinger sig op, jf. analysen. I slutstrofen af nr. 25 rinder »Ordets Bække« $(7,4)$ gennem sangen, som lyder »sødt med Barne-Røst « $(7,5)$. Således forstærker en intertekstuel læsning billedet af de syngende som kvinder, der hermed fremstår som dem, der forløser ordet gennem sangen. Dagvisens forl $\varnothing \mathrm{b}$ endte med et billede af vinteren og døden, som nærmede sig med naturens lovmæssighed (16.8). Denne salme slutter med den modsatte opfattelse: at naturens lovmæssighed er brudt, og at vinteren ikke forekommer mere. (76)

Kigger vi imidlertid referencen med de to billeder af bækken efter, bliver det mere end problematisk. De to citater lyder:

nr. 16, 7:

$\mathrm{Nu}$ sagtelig skrid, vor Høitids-Dag,

Med Straaler i Krands om Tinde!

Hver Time til Herrens Velbehag

Som Bækkene smaa henrinde, Til frydelig de sig snoe i Mag

Op under de grønne Linde.

nr. 25, 7:

Lyd da høit, vor Fryde-Sang,

Mens vi Negen binde!

Frydelig i Dane-Vang

Ordets Bække rinde, 
Sjunge sødt med Barne-Røst:

Vaar og Sommer, gylden Høst,

Vinter aldrig mere!

Problemet er, at bækkene i de to citater er billeder på to vidt forskellige ting: i nr. 16 på tidens gang og i nr. 25 på menneskets sang. Det er altså udelukkende ordet »bække«, som udløser forbindelsen, og det er kun ordet »Børne-Røst«, som kan fremkalde henvisningen til kvinderne fra nr. 16 (som jeg heller ikke kan få øje på), mens der ikke bides mærke i, at den syngende stemme i strofe 6 af nr. 25 beskrives »bag Ploven « og altså må være mandlig, hvis der skal foretages en kønsbestemmelse.

Yderligere besværligt bliver det, fordi der kunne identificeres andre og måske mere oplagte billedmæssige forlæg for bækken i nr. 25, metaforer knyttet til vand er nemlig blandt dem, Grundtvig benytter sig mest af, og kigger vi fx i Nyaars-Morgen, kan vi finde følgende formulering, hvor bækkene endda er fremhævet af digtets eneste afvigelse fra sit metrum ( »den Gamle« er her formentlig »sprogmesterinden « Malene):

Der døde den Gamle,

Da alt jeg var stor,

For stor til at samle

De fyndige Ord,

De Vendinger snilde,

De mange Bække smaa,

Fra Valdemars Kilde,

Som gjøre Sus-Aa;

Dog hjalp hun, for Føden,

Mig Stodder af Nøden,

Dengang jeg blev lille igjen! (str. 283)

Strofen her er faktisk en mere oplagt parallel, fordi det er den menneskelige tale, som her danner bækken, ligesom det i SV 25 er den menneskelige sang, så de to billeder ligger meget tættere op af hinanden, end SV 16 og 25, og kommer vi nogle få strofer længere hen i NyaarsMorgen, bliver bækkene viderebearbejdet, så de bliver til »vor Moder «s børn, således at den intertekstuelle reference er perfekt, hvis man vil se den. Dette være ikke sagt for at hævde, at denne reference faktisk er korrekt, og at SV 25 på dette sted faktisk henviser til Nyaars-Morgen, 
men for at vise, at det er betydeligt nemmere at sandsynliggøre dén reference, end den Rode faktisk mener at se.

Et tilsvarende og endnu værre problem er Rodes brug af døgnmetaforikken og i særdeleshed billedet af Kristus som solen. Her skriver hun bl.a. om den første salme i andet hæfte, som er en gendigtning af en Davidssalme:

Med optaktens solopgangsbillede, der ikke findes i forlægget, sætter Grundtvig salmen ind i en metaforisk sammenhæng med hæfte 1, hvor solen var det gennemgående symbol på Kristus. (84f)

Men også denne reference må stå som ganske tvivlsom, fordi solen generelt i Grundtvigs forfatterskab, og fx igen i Nyaars-Morgen er billede på Kristus. Dermed kunne man med stor ret hævde, at det, Grundtvig gør, når han indsætter solopgangsbilledet i Davidssalmen som Kristusbillede, ikke er, at han viser tilbage til første hæfte, men at han indsætter salmen i sin egen generelle billedverden.

I begge disse tilfælde sker der, så vidt jeg kan se det, at Randi Rode lader sig forlede af sin intertekstuelle metode - blandt andet fordi hun har et for ureflekteret forhold til den - til at hævde eksistensen af sammenhænge, der for mig må forblive postulater.

Dermed er sådan set også mit andet spørgsmål til Barneglad og engleklog antydet: jeg har stort besvær med at få øje på en stor del af de intertekstuelle referencer, Barneglad og engleklog mener at have beskrevet, og dermed har jeg også meget svært ved at acceptere de udviklingslinjer i værket og den helhedslæsning, der er bogens pointe. I første omgang må det siges, at overhovedet forestillingen om, at digterstemmen gennemløber en udvikling igennem Sang-Vark til den danske Kirke, er problematisk, fordi det - i hvert fald i Randi Rodes udlægning - betyder, at der er træk i de tidlige salmer, som dementeres af, hvad der siges i senere salmer. Konsekvensen af det er, at de ikke længere i sig selv kan forstås som autentiske trosudtryk. Det betyder at en række af de tidlige tekster i sangværket må opfattes som ubrugelige til salmesang, hvis Randi Rodes fortolkning holder. Det kan godt være, at menigheden med stor forn $\varnothing$ jelse synger Den signede Dag, men if $\varnothing$ lge Barneglad og engleklog ved Grundtvig, som det fremgår af det tidligere citerede stykke fra bogen, at det, som står i salmen, på afgørende punkter er forkert. Alene dén konsekvens gør mig skeptisk over for tolkningen. 
Et videre problematisk træk ved bogen er det besvær, hvormed den læses, og hvormed man følger argumentationen igennem de mange analyser. Når man befinder sig i indledningen, afslutningen og de sammenfatninger, Randi Rode foretager undervejs, er tesen klart og tydeligt til stede og fremsættes med stor overbevisning, men så snart man går ind $i$ analyserne, begynder billedet at flimre: hvad er det for udviklinger, der sker, fra og til hvilke positioner bevæger værket sig, og hvordan forholder den enkelte analyse sig til overstrukturen i værket? Man overvældes med krydshenvisninger og udsagn om dette og hint i teksten, men overblikket vil ikke indfinde sig. Hvis den udvikling, Barneglad og engleklog ser i Sang-Vark til den danske Kirke er klar, er den i hvert fald ikke så klar, at man har nemt ved at forstå, hvad den mere nøjagtigt går ud på.

Mine problemer med at følge Barneglad og engleklogs tese begynder sådan set allerede i bogens gennemgang af de strofer, Grundtvig har udvalgt fra Nyaars-Morgen til at danne sangværkets forspil. Rode fortolker udvalget som tegn på en bevidsthed hos Grundtvig om, at han ikke fik opfyldt de store mål, han profeterede om i Nyaars-Morgen, hvorfor de første salmer i Sang-Vark til den danske Kirke forstås som Grundtvigs fornyede gennemarbejdning af sit livs problemer. Som belæg angiver hun, som sagt, at den sidste strofe fra Nyaars-Morgen, der er taget med, placerer Grundtvig i midvintermørket og ikke i den klart oplyste sommerdag, der afslutter originalværket. Dermed overser hun imidlertid hovedpointen i redaktionen, nemlig at For-Spil ved at slutte i Nyaars-Morgens 4. sang kommer til at handle om bevægelsen hen imod en digterisk inspiration. Det uddrag, Grundtvig har lavet fra Nyaars-Morgen, viser, hvordan han får en fjer af Helligånden at skrive med, og dernæst bliver sat ned foran sin store opgave, den, der er blevet sat for ham med duens tilsynekomst. Det viser resten af Sang-Vark til den danske Kirke som resultatet af denne inspiration og er sådan set et stykke storhedsvanvid fra Grundtvigs side: Sangværket er skrevet med en fjer af Helligånden, og det er endda Ånden selv, som bevæger den. Og dermed bliver også hendes fortolkning af slutstrofen gal, fordi det netop ikke er en fortvivlet position, Grundtvig befinder sig i her. Han er placeret i mørket, men han har ånden med sig og sin store opgave foran sig, han er ikke personligt i krise (hvad der i øvrigt også fremgår af Nyaars-Morgen).

Går man derfra videre ind i Barneglad og engleklogs gennemgang af sangværket, bliver billedet yderligere flimrende. Man kastes rundt imellem de forskellige tekster i værkets første del, og betydninger, som 
er fremanalyseret i en salme, bruges frit som fældende bevismateriale eller som sikker præmis i analysen af senere salmer. Derfor er man, hvis man vil følge med i Barneglad og engleklog, sådan set nødt til at sætte læsetempoet radikalt ned og studere bogen sideløbende med, at man læser selve sangværket. Men så snart man gør det, begynder tvivlspunkterne at melde sig. Der er så mange usikkerheder i Barneglad og engleklog, at i hvert fald undertegnede ikke kan se, hvor jeg skal begynde og hvor jeg skal holde op. Jeg mener, at der er problemer både $\mathrm{i}$ bogens analyser af de enkelte salmer, i sammenfatningerne og i særdeleshed i beskrivelsen af dé intertekstuelle forbindelser imellem salmerne, som er hele bogens pointe.

Et par eksempler er for så vidt allerede givet. Den direkte bevisværdi af sådanne enkelteksempler er tvivlsom, og pladsen tillader mig ikke at give tilstrækkeligt mange eksempler til at gøre dem repræsentative. Det er der i nærværende sammenhæng ikke noget at gøre ved andet end at give et lidt mere overordnet eksempel. Det drejer sig om en passage fra et af de væsentligste af de overblik, Randi Rode giver, nemlig den tidligere nævnte passage »Afsnit 2 og 4 læst som slægtsdrama«, som står sammen med konklusion på Randi Rodes læsning af de første 23 salmer i sangværket. De to afsnit, som der henvises til, synes at omfatte salmerne 9 - 13 (afsnit 2) og 19 -23 (afsnit 4).

Randi Rode ridser slægtsdramaet op som en modsætning imellem en mandlig og en kvindelig side af familien, og specifikt synes den at handle om sønnernes udvikling. Den første passage lyder således, og jeg citerer endnu en gang et længere stykke:

Rammen omkring sønnerne er en kernefamilie, bestående af oprindelig en fader, en moder og et antal brødre og søstre. Af denne søskendeflok er der en, der skiller sig ud på flere måder. Han er familiens kronikør, og slægtshistorien fortælles således ud fra hans synsvinkel. Han er familiens artige dreng, en følsom type, der foretrækker søstrenes selskab frem for brødrenes. Da sønnens historie begynder (nr. 8), er faderen åbenbart død (1), og sønnen fortæller, hvordan det gik med ham og de andre brødre efter hans død (5-6). Der skete det, at brødrene efterhånden gjorde oprør og nægtede at følge faderens opdragelsesprincipper (6), som han havde skrevet i en bog, der til sidst graves ned i protest af brødrene (7). Den artige broder, som stadig følger faderautoritetens opdragelsesprincipper, betragter brødrenes adfærd med vrede og forargelse (8). Han kan 
kun håbe på, at faderens løfte om bogens genopdukken engang må gå i opfyldelse (9).

Brødrene fordriver ham fra barndomshjemmet, og i næste scene (nr. 9) finder vi ham (og søstrene) siddende grædende i et fremmed land, hvor de længes efter moderen $(1,3)$ og barndomshjemmet $(1,4)$. De er her omgivet af fjender $(2 \operatorname{og} 6)$, der er lige så onde som brødrene, og de fordrevne søskende anråber faderen om hævn (7-8). I tiden mellem denne og den følgende scene (nr. 10) er han og søstrene kommet hjem igen, og brødrene er nu gået helt bersærk $<\ldots$. .. (69)

Tager man Barneglad og engleklogs grundlæggende påstand om en kontinuitet fra salme til salme som udgangspunkt, så er det i første omgang slående, at sådan som udviklingen fremstilles her, så sker der en række afgørende brud imellem salmerne. Der er ikke noget udsagn nogen steder i selve teksterne om, hvordan man kom fra den ene situation til den anden. Vi henvises to gange blot til, at nu er der en ny scene, og alt det, som forvolder skiftet fra den ene scene til den anden, henstår uforklaret. Det er kun bogens beslutning om, at de er forbundne, der skaber forbindelsen, og Barneglad og engleklog må da også omhyggeligt forklare, hvad det er, der leder fra den ene »scene« til den anden, læseren har ingen chance for at se det selv. Tager man den omhyggelige kausalitet, der råder i Grundtvigs andre stordigte, i betragtning, er dette påfaldende.

Videre problematisk bliver det, når man begynder at gå analysen lidt nøjere igennem. Salme nr. 8 i sangværket er I Vittenberg I SachsenLand, som er et kort uddrag fra Grundtvigs meget tidligere dødedigt over Frants Volkmar Reinhardt. Den beskriver, hvordan Luther åbnede Bibelen for hvermand og dernæst, hvordan man efter Luthers død har forsmået den og villet begrave den. Den skikkelse, Randi Rode her identificerer som "Faderen «, er altså Luther, og salmen markerer tydeligt, at der er en herskerskikkelse, Gud, over Luther, men kommer man hen i de efterfølgende salmer, så er den skikkelse, Randi Rode identificerer med faderen tydeligvis Gud. Endnu mere problematisk bliver det, fordi Luther intetsteds i nr. 8 faktisk omtales som »fader «, ligesom de, der gør oprør med Bibelen ikke identificeres som hans sønner (men derimod nok som sønner af hinanden), derimod omtales Gud eksplicit som »Fader i det Høie « (4,1). Yderligere hævdes det i den citerede passage, at den bog, som blev begravet, var skrevet af denne nu afdøde fader (Luther), men det står der intet om i salmen. Bogen er ikke 
»en bog «, det er Bibelen, og omtales derudover faktisk som »Herrens Bog « i selve salmen. Det ville altså være i direkte modstrid med salmens egen tanke såvel som med al kendt kirkehistorie, hvis Luther havde skrevet dén.

Bedre bliver det ikke, hvis man kigger efter, hvem det faktisk er, der råbes efter hævn over i den niende salmes afslutning, det er nemlig den eneste datter, der overhovedet omtales i de tre salmer:

Ja, Babylons Daatter, Med bangeste Kaar!

Den Tanke mig gotter, Din Time dog slaaer, Du undgaaer det ikke Den Skaal at uddrikke, Du skiænkde for os!

Med Helvedes Glæde,

Det husker du nok, Du slog vore Spæde Mod Steen og mod Stok; Fra Israels Dommer Giengældelsen kommer, Til Lykke med den!

Vender man fra denne gennemgang tilbage til Barneglad og engleklogs oprindelige analyser af de salmer, som indgår i denne passage (p. 4144), kan man se, at disse analyser forbløffende nok ikke eller kun meget sparsomt peger fremad imod denne læsning af passagen som del af et familiedrama.

Jeg afbryder her min gennemgang af såvel denne passage som af bogen i sin helhed. En videre gennemgang af bogen måtte fra min side tage samme form som det, der allerede her er præsenteret, og det ville hurtigt blive til en pointel $\varnothing$ s opremsning. Jeg føler mig tvunget til at konkludere, at jeg ikke kan tilslutte mig Barneglad og engleklogs udlægning af Sang-Vark til den danske Kirke. Det er beklageligt, fordi det er et interessant fortolkningsmæssigt projekt, Randi Rode har givet sig ud i; det er ubestrideligt en god idé at forsøge at opfatte sangværket som en "gennemkomponeret helhed «. Men efter at have læst Barneglad og engleklog er jeg desværre så godt som overbevist om, at hvis sangværket 
er gennemkomponeret, så er kompositionen ikke den, Randi Rode beskriver.

\section{Noter}

1 Sidehenvisningerne i citatet er til Michael Worton (mfl.), Intertextuality, Theories and Practices, Manchester 1990. Jeg noterer mig med en vis bekymring, at dette værk er Barneglad og engleklogs eneste teoretiske reference til begrebet intertekstualitet.

2 Dog er disse typer referencer ikke mere specielle for netop sangværket end at tilsvarende spørgsmål rejser sig eller kan rejse sig i forbindelse med mange andre tekstsammenstillinger såsom digtsamlinger.

3 Her er en mindre korrekturfejl, da dagvisen er nr. 16 i sangværket. 